\title{
Use of AbobotulinumtoxinA for Cosmetic Treatments in the Neck, and Middle and Lower Areas of the Face: A Systematic Review
}

\author{
Hassan Galadari ${ }^{1, *(\mathbb{D})}$, Ibrahim Galadari ${ }^{1}$, Riekie Smit ${ }^{2}$, Inna Prygova ${ }^{3}$ and Alessio Redaelli ${ }^{4}(\mathbb{D}$ \\ 1 College of Medicine and Health Sciences, United Arab Emirates University, \\ Al Ain P.O. Box 17666, United Arab Emirates; galadari@email.com \\ 2 Riekie Smit Practice, Pretoria 0182, South Africa; riekiesmit@icloud.com \\ 3 Ipsen Pharmaceutical, 92100 Boulogne-Billancourt, France; inna.prygova@galderma.com \\ 4 Visconti di Modrone Medical Center, 20122 Milan, Italy; mail@docredaelli.com \\ * Correspondence: hgaladari@uaeu.ac.ae; Tel.: +971-03-7137571
}

Citation: Galadari, H.; Galadari, I.; Smit, R.; Prygova, I.; Redaelli, A. Use of AbobotulinumtoxinA for Cosmetic Treatments in the Neck, and Middle and Lower Areas of the Face: A Systematic Review. Toxins 2021, 13, 169. https://doi.org/ 10.3390/toxins13020169

Received: 18 January 2021

Accepted: 15 February 2021

Published: 22 February 2021

Publisher's Note: MDPI stays neutral with regard to jurisdictional claims in published maps and institutional affiliations.

Copyright: (C) 2021 by the authors. Licensee MDPI, Basel, Switzerland. This article is an open access article distributed under the terms and conditions of the Creative Commons Attribution (CC BY) license (https:/ / creativecommons.org/licenses/by/ $4.0 /)$.

\begin{abstract}
AbobotulinumtoxinA (aboBoNT-A) has been used for various cosmetic purposes, including minimization of moderate to severe lines, or other cosmetic indications, in the face and neck. We carried out a systematic review to identify all relevant evidence on the treatment approaches and outcomes of aboBoNT-A as a cosmetic treatment of the middle and lower areas of the face, and the neck. Embase, MEDLINE, Cochrane Library, congress proceedings and review bibliographies were searched for relevant studies. Identified articles were screened against pre-specified eligibility criteria. Of 560 unique articles identified, 10 were included for data extraction (three observational studies, 1 randomized controlled trial [with two articles] and five non-randomized trials). The articles provided data on gummy/asymmetric smile (2), marionette lines (5), masseter muscle volume (2), nasal wrinkles (2), perioral wrinkles (3) and the platysma muscle (4). All articles reporting on efficacy of aboBoNT-A demonstrated positive results, including reduction of wrinkles (5), reduction of masseter muscle (2) and degree of gummy smile (1) compared with before treatment. No serious adverse events were reported and patient satisfaction was high. In conclusion, positive findings support further research of aboBoNT-A for the middle and lower areas of the face, and in the neck, which are largely unapproved indications.
\end{abstract}

Keywords: abobotulinumtoxinA; botulinum toxin; lower face; marionette lines; masseter; neck; perioral area; platysma; middle face

Key Contribution: Evidence from this systematic literature review demonstrates that aboBoNT-A has the potential to be an effective cosmetic treatment in the middle and lower regions of the face and in the neck, with high levels of patient satisfaction and no serious adverse events. Our study identified a range of treatment approaches and evidence gaps in the literature; further research is needed to establish consistent treatment approaches to optimize patient outcomes.

\section{Introduction}

Botulinum neurotoxin type-A injections are currently the most popular type of cosmetic procedure worldwide [1-4]. The neurotoxin reduces muscle contractions by blocking the release of the neurotransmitter acetylcholine and can be used to minimize wrinkles and other conditions, caused by repeated movements and muscle contractions $[5,6]$. There are several preparations of botulinum neurotoxin type-A available for aesthetic use [6-8]. Three of the well-known preparations, which have different manufacturing processes and properties, are available worldwide: abobotulinumtoxinA (aboBoNT-A; Dysport ${ }^{\circledR}$, Ipsen Biopharm Ltd., Wrexham, UK; Azzalure ${ }^{\circledR}$, Galderma Ltd., Lausanne, Switzerland), onabotulinumtoxinA (onaBoNT-A; Botox ${ }^{\circledR}$, Allergan, Irvine, CA, USA), and incobotulinumtoxinA (incoBoNT-A; Xeomin ${ }^{\circledR}$, Merz Pharmaceuticals GmbH, Frankfurt, Germany) [9-12]. 
For aesthetic treatment, aboBoNT-A (Dysport 300 unit vial [Speywood units]) is approved in the USA by the Food and Drug Administration for the temporary improvement in the appearance of moderate to severe glabellar lines associated with procerus and corrugator muscle activity in adult patients less than 65 years of age [10]. In the EU, it is indicated (Azzalure 125 unit vial) for the temporary improvement in the appearance of moderate to severe glabellar lines seen at frown and/or lateral canthal lines seen at maximum smile, in adult patients less than 65 years, when the severity of these lines has an important effect on the psychological well-being of the patient [13]. It is approved in many other countries worldwide for glabellar lines and other aesthetic indications, although it is common for physicians to use aboBoNT-A to treat wrinkles and lines in other areas of the face and neck [14,15]. Several consensus recommendations for the use of aboBoNT-A for treatment of wrinkles or other cosmetic indications on the middle and lower face, and neck and chest have been developed $[4,14,16,17]$. These recommendations provide information on the number and location of the injection points, the dose of individual injection points, the combined dose of multiple injection points, the injection technique and safety concerns for each area $[4,14,16,17]$.

Owing to its approved indications, most research on the cosmetic use of aboBoNT-A is in relation to glabellar lines and the upper area of the face [18-20]. As such, there is a paucity of research on the use of aboBoNT-A in the middle and lower regions of the face and in the neck. The aim of this systematic literature review (SLR) was to assess the evidence regarding treatment approaches, efficacy, safety and patient-reported outcomes relating to aboBoNT-A for cosmetic treatment for several indications for which aboBoNT-A is largely unapproved, namely, treatment of the neck and of middle and lower areas of the face.

\section{Results}

\subsection{Systematic Review of the Literature}

A total of 625 papers were identified in the electronic database searches; 65 duplicate papers were excluded before citation screening and 510 papers were excluded during citation screening (Figure 1). There were no relevant studies identified in the supplementary searches, and 40 of the remaining 50 papers were excluded during full-text review, leaving 10 studies (three observational studies [OSs] [21-23], five non-randomized controlled trials [24-28] and two studies reporting data from one randomized controlled trial [RCT] $[29,30])$ included in the SLR. In the included studies, sample size ranged from 10 to 383 patients, mean age was 32.8 to 55.9 years and percentage of female participants was $92.7 \%$ to $100 \%$ across six studies that reported gender. Three studies were conducted in Brazil [22,29,30], two in Lebanon [24,26], two in the USA [21,27] and one each in South Korea [25], Taiwan [28] and Thailand [23]. Six of the studies looked at aboBoNT-A injections in various parts of the middle and lower regions of the face for the treatment of various conditions, including lower eyelid wrinkles, nasal wrinkles, platysmal bands at rest and at maximal contraction and marionette lines $[23,24,26,27,29,30]$. Of the remaining four studies, two looked at patients that received injections in the masseter muscles $[25,28]$, one looked only at treatments for excessive gingival display (gummy smile) [22] and one looked at injections in the platysma muscle only [21].

\subsection{Treatment Approaches}

Treatment approaches are summarized, by study, in Table 1, and by indication, in Table 2 and Figure 2. All except one study [27] included approaches to toxin dilution. In eight studies, aboBoNT-A was diluted in saline to produce concentrations ranging from 70 to $250 \mathrm{U} / \mathrm{mL}$ (most often 2 or $2.5 \mathrm{~mL}$ normal saline to dilute $500 \mathrm{U}$ of aboBoNT-A) for different indications (Figure 2) [21-26,29,30]. In one study, aboBoNT-A was diluted in sterile distilled water to produce a concentration of $200 \mathrm{U} / \mathrm{mL}$ for the reduction of masseter muscle volume [28]. Table 1 provides details of the specific areas injected in each study. Participants were injected in one $[22,27,28]$ or two $[24,25,29,30]$ treatment sessions; three 
studies did not report injection frequency $[21,23,26]$. Only one study reported the use of topical anaesthesia, in which patients were treated with a cream containing lidocaine and prilocaine before injection [22]. The number of injection points varied with area of treatment, ranging from two for treatment of anterior gummy smile [22] to 12 for injections into the platysma muscle [21]. In one study looking at injections for rejuvenation of the neck using a multiple-injection technique, participants received approximately 150 micro injections (mean total dose of $154 \mathrm{U}$ aboBoNT-A) across the anterior region of the neck [26].

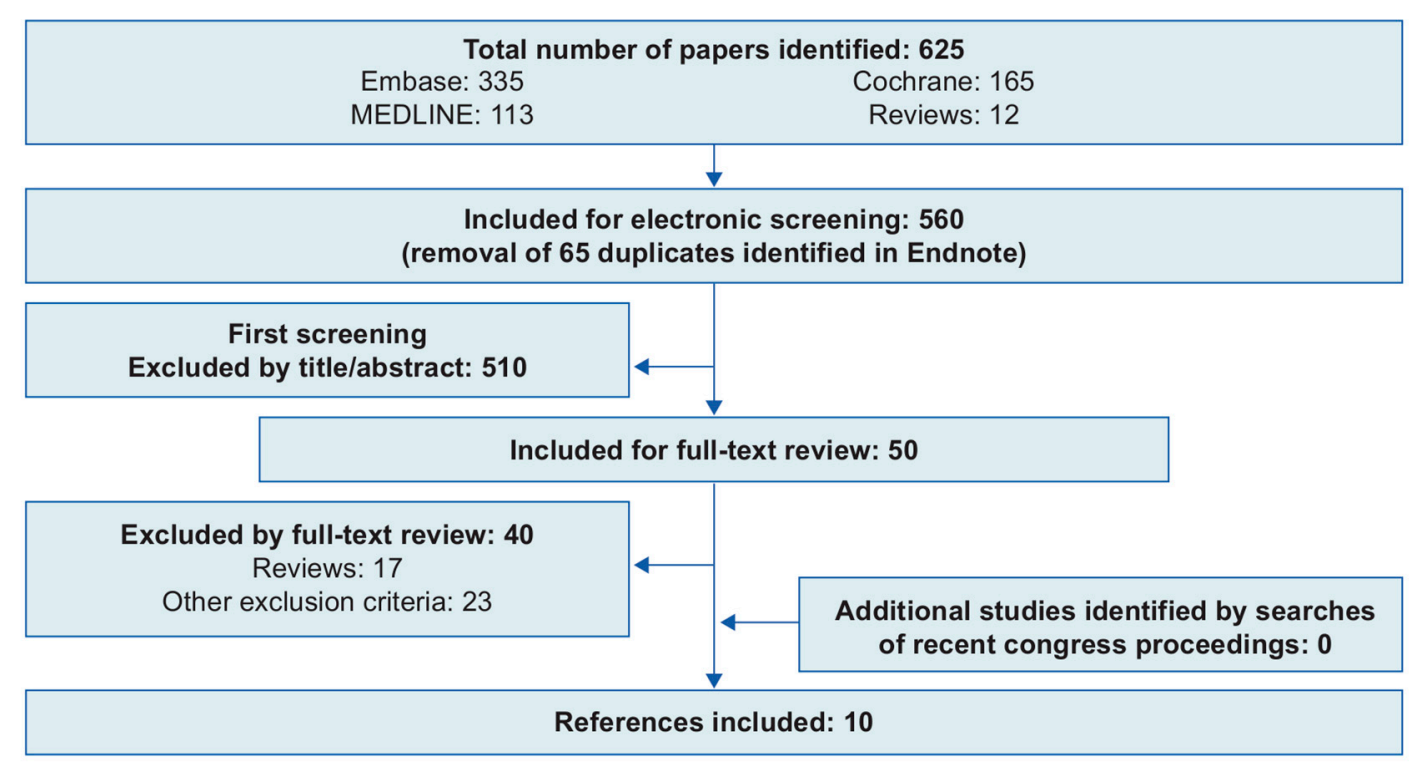

Figure 1. Preferred Reporting Items for Systematic Reviews and Meta-Analyses flow diagram. References were excluded at full-text review stage owing to no relevant data as follows: (1) duplicates, (2) editorial/commentary, (3) population not of interest, (4) intervention not of interest (not aboBoNT-A), (5) outcomes not of interest, (6) study design (non-randomized controlled trial/modeling study/case series or studies), (7) study not in English, (8) in vitro/animal study and (9) website source. Narrative reviews were included for first screening so that any relevant cited studies could be identified and were excluded at full-text review.

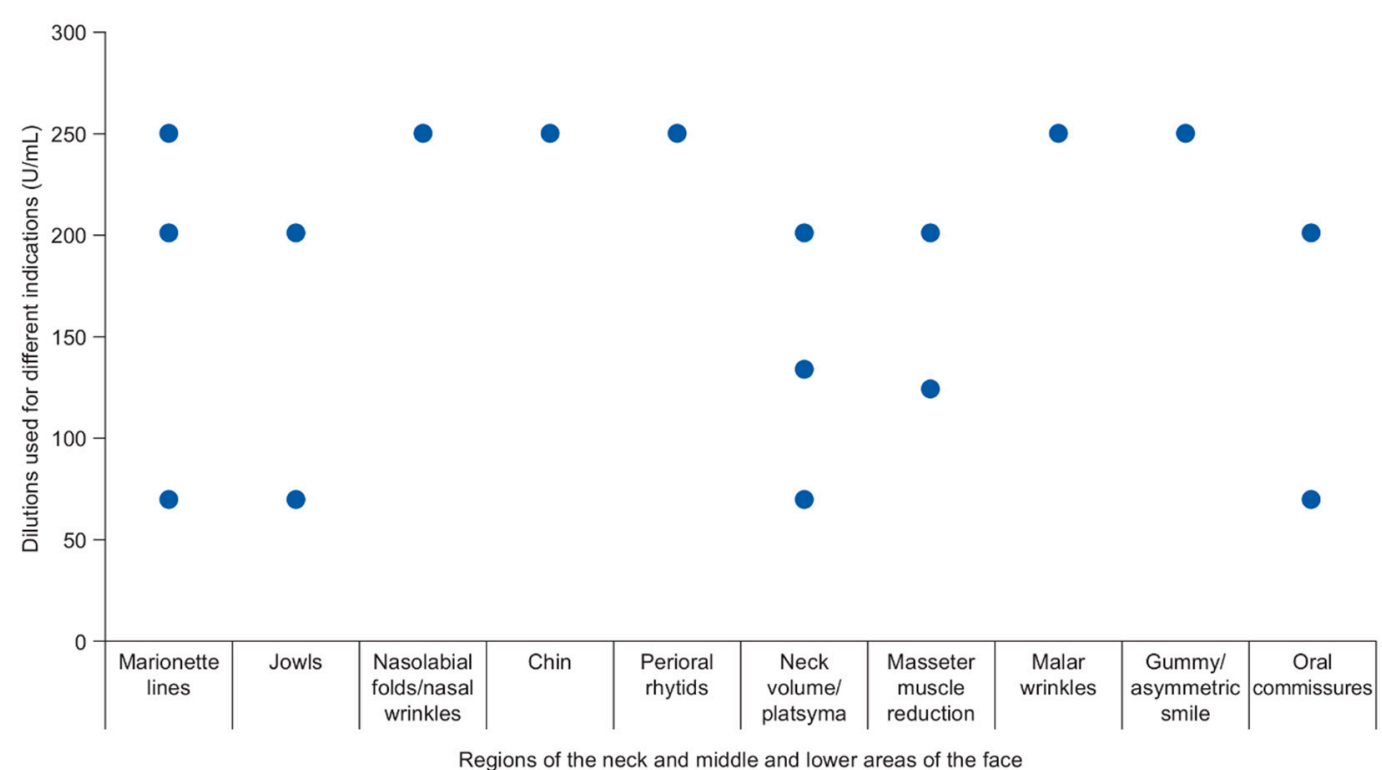

Figure 2. AbobotulinumtoxinA dilutions used for different indications. 
Table 1. AbobotulinumtoxinA (aboBoNT-A) treatment approaches, by study.

\begin{tabular}{|c|c|c|c|c|c|c|c|c|c|}
\hline Study & Study Design & Country & Age, Years & $\begin{array}{l}\text { Participants, N (n [\%] } \\
\text { Women, n [\%] Men) }\end{array}$ & $\begin{array}{l}\text { Area(s) of Injection. } \\
\text { Further Details }\end{array}$ & Indication Assessed & $\begin{array}{l}\text { Total Dose and } \\
\text { Number of } \\
\text { Injection Points }\end{array}$ & $\begin{array}{l}\text { Injection } \\
\text { Frequency }\end{array}$ & $\begin{array}{l}\text { AbobotulinumtoxinA } \\
\text { Dilution }\end{array}$ \\
\hline $\begin{array}{l}\text { Awaida et al., } \\
2018 \text { [26] }\end{array}$ & $\begin{array}{l}\text { Non- } \\
\text { randomized } \\
\text { controlled } \\
\text { trial }\end{array}$ & Lebanon & $\begin{array}{l}\text { Mean (SD): } \\
55.9(5.8)\end{array}$ & 25 (25 [100\%] women) & $\begin{array}{l}\text { Neck, lower face. } \\
\text { Injections were } \\
\text { administered over the } \\
\text { entire anterior neck }\end{array}$ & $\begin{array}{l}\text { Oral commissures, } \\
\text { marionette lines, jowls, } \\
\text { neck volume, } \\
\text { platysmal bands at } \\
\text { rest and at maximal } \\
\text { contraction }\end{array}$ & $\begin{array}{l}\text { Mean (SD) dose of } \\
154(28.6) \text { U in } 150 \\
\text { points of injection }\end{array}$ & NR & $\begin{array}{l}500 \mathrm{U} \text { vial } \\
\text { reconstituted in } \\
\text { normal saline to a } \\
\text { concentration of } \\
70 \mathrm{U} / \mathrm{mL}\end{array}$ \\
\hline $\begin{array}{l}\text { Chang et al., } \\
2018 \text { [27] }\end{array}$ & $\begin{array}{l}\text { Non- } \\
\text { randomized } \\
\text { controlled } \\
\text { trial }\end{array}$ & USA & $\begin{array}{c}\text { Mean: } 51.7 \\
\text { Range: } 28.8-72.4\end{array}$ & $32(32[100 \%]$ women $)$ & $\begin{array}{l}\text { Lower face. Left upper, } \\
\text { right upper, left lower, } \\
\text { and right lower } \\
\text { cutaneous lip }\end{array}$ & $\begin{array}{l}\text { Perioral rhytids, } \\
\text { marionette lines, chin, } \\
\text { nasolabial fold, oral } \\
\text { commissures, cheeks }\end{array}$ & $\begin{array}{l}4-5 \mathrm{U} \text { per point in } \\
\text { four points (left } \\
\text { upper, right upper, } \\
\text { left lower and } \\
\text { right lower } \\
\text { cutaneous lip; } \\
18 \mathrm{U} \text { in total) }\end{array}$ & One session & NR \\
\hline $\begin{array}{c}\text { Hevia } \\
2010[21]\end{array}$ & $\begin{array}{l}\text { Observational } \\
\text { study }\end{array}$ & USA & $\begin{array}{c}\text { Mean: } 50^{1} \\
\text { Range: } 21.0-78.0^{1}\end{array}$ & $43^{2}(\mathrm{NR})$ & Neck. Platysma & Platysma & $\begin{array}{c}\text { 4-12 injections } \\
\text { (50-160 U in total) }\end{array}$ & NR & $\begin{array}{c}300 \mathrm{U} \text { was } \\
\text { reconstituted with } \\
2.25 \mathrm{~mL} \text { of } 0.9 \% \text { saline, } \\
\text { resulting in } \\
\text { concentration of } \\
133 \mathrm{U} / \mathrm{mL}\end{array}$ \\
\hline $\begin{array}{l}\text { Hexsel et al., } \\
2013 \text { [30] }\end{array}$ & $\mathrm{RCT}$ & Brazil & $\begin{array}{c}\text { Mean (SD): } \\
48.3(7.2) \\
\text { Range: } 30.0-60.0\end{array}$ & $\begin{array}{c}85 \text { (82 [96.5\%] women; } \\
3[3.5 \%] \text { men })\end{array}$ & $\begin{array}{l}\text { Mid, lower face. In } \\
\text { each third of the face, } \\
\text { at least two of the } \\
\text { assessed indications } \\
\text { (see next column) } \\
\text { were injected }\end{array}$ & $\begin{array}{c}\text { Lower eyelid wrinkles, } \\
\text { nasal wrinkles, malar } \\
\text { wrinkles, perioral } \\
\text { wrinkles, marionette } \\
\text { lines, } \\
\text { gummy/asymmetric } \\
\text { smile, cellulitic chin }\end{array}$ & $\begin{array}{c}\text { Comparison of } \\
120-165 \mathrm{U}, \\
166-205 \mathrm{U} \text { and } \\
206-250 \mathrm{U} \\
\text { Number of } \\
\text { injection } \\
\text { points NR }\end{array}$ & $\geq 2$ sessions & $\begin{array}{c}500 \mathrm{U} \text { reconstituted in } \\
2 \mathrm{~mL} \text { of } 0.9 \% \text { sterile } \\
\text { saline, resulting in } \\
250 \mathrm{U} / \mathrm{mL}\end{array}$ \\
\hline $\begin{array}{l}\text { Hexsel et al., } \\
2013 \text { [29] }\end{array}$ & $\mathrm{RCT}$ & Brazil & & \multicolumn{6}{|c|}{ As above (Hexsel et al., 2013 [30]) } \\
\hline
\end{tabular}


Table 1. Cont.

\begin{tabular}{|c|c|c|c|c|c|c|c|c|c|}
\hline Study & Study Design & Country & Age, Years & $\begin{array}{l}\text { Participants, N (n [\%] } \\
\text { Women, } \mathrm{n}[\%] \text { Men) }\end{array}$ & $\begin{array}{l}\text { Area(s) of Injection. } \\
\text { Further Details }\end{array}$ & Indication Assessed & $\begin{array}{l}\text { Total Dose and } \\
\text { Number of } \\
\text { Injection Points }\end{array}$ & $\begin{array}{l}\text { Injection } \\
\text { Frequency }\end{array}$ & $\begin{array}{l}\text { AbobotulinumtoxinA } \\
\text { Dilution }\end{array}$ \\
\hline $\begin{array}{l}\text { Jabbour et al., } \\
2017 \text { [24] }\end{array}$ & $\begin{array}{l}\text { Non- } \\
\text { randomized } \\
\text { controlled } \\
\text { trial }\end{array}$ & Lebanon & $\begin{array}{l}\text { Mean (SD): } \\
54.8(5.3)\end{array}$ & 30 (30 [100\%] women) & $\begin{array}{c}\text { Lower face, neck. } \\
\text { Injections } \\
\text { administered } 1-2 \mathrm{~cm} \\
\text { apart on a horizontal } \\
\text { line under } \\
\text { the mandibular border, } \\
\text { followed by platysmal } \\
\text { band injections } 2 \mathrm{~cm} \\
\text { apart, vertically }\end{array}$ & $\begin{array}{l}\text { Jowls, platysmal } \\
\text { bands at rest and at } \\
\text { maximal contraction, } \\
\text { marionette lines, neck } \\
\text { volume, oral } \\
\text { commissures }\end{array}$ & $\begin{array}{l}125 \mathrm{U} \text { maximum } \\
\text { for global neck } \\
\text { treatment per } \\
\text { injection session } \\
\text { (5 U per point in } \\
2-4 \text { points on each } \\
\text { platysmal bands } \\
\text { and for } \\
\text { mandibular } \\
\text { border) } \\
\text { Mean (SD) dose of } \\
114.3 \text { (13.7) U }\end{array}$ & Two sessions & $\begin{array}{l}500 \mathrm{U} \text { reconstituted in } \\
2.5 \mathrm{~mL} \text { of sterile saline }\end{array}$ \\
\hline $\begin{array}{l}\text { Kim et al., } \\
2005 \text { [25] }\end{array}$ & $\begin{array}{l}\text { Non- } \\
\text { randomized } \\
\text { controlled } \\
\text { trial }\end{array}$ & South Korea & $\begin{array}{c}\text { Age ranges: } \\
\text { 13-19 years } \\
(\mathrm{n}=10) \\
20-29 \text { years } \\
(\mathrm{n}=293) \\
30-39 \text { years } \\
(\mathrm{n}=70) \\
40-49 \text { years }(\mathrm{n}=9)\end{array}$ & $\begin{array}{c}383(355[92.7 \%] \\
\text { women; } 28[7.3 \%] \\
\text { men) }\end{array}$ & $\begin{array}{l}\text { Lower face. Within } \\
1.5 \mathrm{~cm} \text { of the mandible } \\
\text { angle border }\end{array}$ & Masseter muscle & $\begin{array}{l}\text { 100-140 U on } \\
\text { each side }\end{array}$ & 1-2 injections & $\begin{array}{l}500 \mathrm{U} \text { reconstituted in } \\
4 \mathrm{~mL} \text { sterile saline to a } \\
\text { final concentration of } \\
125 \mathrm{U} / \mathrm{mL}\end{array}$ \\
\hline $\begin{array}{l}\text { Mazzuco and } \\
\text { Hexsel } \\
2010 \text { [22] }\end{array}$ & $\begin{array}{l}\text { Observational } \\
\text { study }\end{array}$ & Brazil & NR & 16 (NR) & $\begin{array}{l}\text { Lower face. Each side } \\
\text { of the nasolabial } \\
\text { fold and/or the malar } \\
\text { region, depending on } \\
\text { type of indication }\end{array}$ & $\begin{array}{l}\text { Gummy smile (ante- } \\
\text { rior/posterior/mixed) }\end{array}$ & $\begin{array}{c}5-15 \mathrm{U} \text { and 2-6 } \\
\text { injection points } \\
\text { depending on } \\
\text { gummy smile type } \\
\text { (see Mazzuco and } \\
\text { Hexsel [22] for full } \\
\text { details) }\end{array}$ & One session & $\begin{array}{l}500 \mathrm{U} \text { diluted in } 2 \mathrm{~mL} \\
\text { of } 0.9 \% \text { sodium } \\
\text { chloride solution }\end{array}$ \\
\hline $\begin{array}{l}\text { Petchngaovilai } \\
2009 \text { [23] }\end{array}$ & $\begin{array}{l}\text { Observational } \\
\text { study }\end{array}$ & Thailand & Range: $27.0-72.0$ & $261(\mathrm{NR})$ & $\begin{array}{l}\text { Mid-lower face. } \\
\text { Mid-face lifting } \\
\text { involving injection of } \\
\text { the platysma and } \\
\text { lateral part of the } \\
\text { orbicularis oculi }\end{array}$ & $\begin{array}{l}\text { Mid-face, including } \\
\text { the platysma }\end{array}$ & $\begin{array}{c}50-70 \text { U per side } \\
\text { Number of } \\
\text { injection points } \\
\text { NR }\end{array}$ & NR & $\begin{array}{l}500 \mathrm{U} \text { diluted in } 7 \mathrm{~mL} \\
\text { of normal saline }\end{array}$ \\
\hline $\begin{array}{l}\text { Yu et al., } \\
2007 \text { [28] }\end{array}$ & $\begin{array}{l}\text { Non- } \\
\text { randomized } \\
\text { controlled } \\
\text { trial }\end{array}$ & Taiwan & $\begin{array}{c}\text { Mean: } 32.8 \\
\text { Range: } 25.0-46.0\end{array}$ & 10 (10 [100\%] women) & $\begin{array}{l}\text { Lower face. At } 1 \mathrm{~cm} \\
\text { intervals on the } \\
\text { masseter muscle }\end{array}$ & Masseter muscle & $\begin{array}{c}120 \mathrm{U} \text { per } \\
\text { masseteric muscle, } \\
20 \mathrm{U} \text { per } 0.1 \mathrm{~mL} \\
\text { over six injections }\end{array}$ & One session & $\begin{array}{c}500 \mathrm{U} \text { per vial diluted } \\
\text { in } 2.5 \mathrm{~mL} \text { of sterile } \\
\text { distilled water to a } \\
\text { concentration of } \\
200 \mathrm{U} / \mathrm{mL}\end{array}$ \\
\hline
\end{tabular}

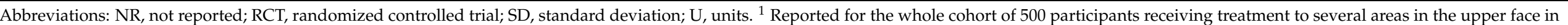
addition to lower face and neck. ${ }^{2}$ Number of treatments to the platysma between June 2009 and February 2010. 
Table 2. AbobotulinumtoxinA (aboBoNT-A) treatment approaches, by indication.

\begin{tabular}{|c|c|c|}
\hline $\begin{array}{c}\text { Regions of the Neck and Middle and Lower } \\
\text { Areas of the Face }\end{array}$ & $\begin{array}{c}\text { Doses Used in Individual Studies (Actual } \\
\text { Dose or Mean/Range Dose Across Patients) }\end{array}$ & $\begin{array}{c}\text { Number of Injection Points Used in } \\
\text { Individual Studies }{ }^{2}\end{array}$ \\
\hline Marionette lines & $\begin{array}{l}18 \text { U; 120-250 U; } 114.3 \text { U; } 154 \text { U } \\
\text { (Chang; Hexsel; Jabbour; Awaida) }\end{array}$ & $\begin{array}{c}2-4 ; 4 ; 150 \\
\text { (Jabbour; Chang; Awaida) }\end{array}$ \\
\hline Jowls & $\begin{array}{c}114.3 \mathrm{U} ; 154 \mathrm{U} \\
\text { (Jabbour; Awaida) }\end{array}$ & $\begin{array}{c}2-4 ; 150 \\
\text { (Jabbour; Awaida) }\end{array}$ \\
\hline Nasolabial folds/nasal wrinkles & $\begin{array}{l}18 \mathrm{U} ; 120-250 \mathrm{U} \\
\text { (Chang; Hexsel) }\end{array}$ & $\begin{array}{c}4 \\
\text { (Chang) }\end{array}$ \\
\hline Chin & $\begin{array}{l}18 \mathrm{U} ; 120-250 \mathrm{U} \\
\text { (Chang; Hexsel) }\end{array}$ & $\begin{array}{c}4 \\
\text { (Chang) }\end{array}$ \\
\hline Perioral rhytids & $\begin{array}{l}18 \mathrm{U} ; 120-250 \mathrm{U} \\
\text { (Chang; Hexsel) }\end{array}$ & $\begin{array}{c}4 \\
\text { (Chang) }\end{array}$ \\
\hline Neck volume/platysma & $\begin{array}{c}\text { 50-70 U; 114.3 U; 50-160 U; } 154 \text { U } \\
\text { (Petchngaovilai; Jabbour; Hevia; Awaida) }\end{array}$ & $\begin{array}{c}2-4 ; 4-12 ; 150 \\
\text { (Jabbour; Hevia; Awaida) }\end{array}$ \\
\hline Masseter muscle reduction & $\begin{array}{c}\text { 100-140 U; } 120 \mathrm{U} \\
(\mathrm{Kim} ; \mathrm{Yu})\end{array}$ & $\begin{array}{c}6 \\
(Y \mathrm{u})\end{array}$ \\
\hline Malar wrinkles & $\begin{array}{l}120-250 \mathrm{U} \\
\text { (Hexsel) }\end{array}$ & $\begin{array}{c}\text { NR } \\
\text { (Hexsel) }\end{array}$ \\
\hline Gummy/asymmetric smile & $\begin{array}{l}\text { 5-15 U; 120-250 U } \\
\text { (Mazzuco; Hexsel) }\end{array}$ & $\begin{array}{c}2-6 \\
\text { (Mazzuco) }\end{array}$ \\
\hline Oral commissures & $\begin{array}{c}18 \mathrm{U} ; 114.3 \mathrm{U} ; 154 \mathrm{U} \\
\text { (Chang; Jabbour; Awaida) }\end{array}$ & $\begin{array}{c}2-4 ; 4 ; 150 \\
\text { (Jabbour; Chang; Awaida) }\end{array}$ \\
\hline
\end{tabular}

Abbreviations: NR, not reported; U, units. References: Awaida et al. [26]; Chang et al. [27]; Hevia et al. [21]; Hexsel et al. [29,30]; Jabbour et al. [24]; Kim et al. [25]; Mazzuco and Hexsel [22]; Petchngaovilai et al. [23]; Yu et al. [23]. ${ }^{1}$ Dose was reported in nine out of 10 included studies. ${ }^{2}$ Number of injections was reported in seven out of 10 included studies.

\subsection{Efficacy Outcomes}

Of the included studies, eight reported efficacy outcomes associated with aboBoNT-A treatment to the neck or lower and middle areas of the face (Table 3) [22-28,30]. In six studies that reported timing of clinical effects, improvement was observed at different follow-up times for different treatment areas $[23-25,27,28,30]$. In one study looking at aboBoNT-A treatment in mid-face lifting (involving injection in the platysma muscle and orbicularis oculi), clinical effect was instantaneous in some cases, but in most cases, changes occurred at 5-10 days [23]; whereas in another study of the effect of aboBoNT-A treatment on lower eyelid wrinkles, nasal wrinkles, malar wrinkles, perioral wrinkles, marionette lines, gummy/asymmetric smile and cellulitic chin, improvement was observed at the first follow-up 4 weeks following treatment [30]. Chang et al. also reported an effect of aboBoNT-A treatment on the magnitude of strain in the cheek, marionette lines, nasolabial folds, oral commissures, upper lip and perioral region as a whole, at the first follow-up 2 weeks following treatment [27]. For reduction of masseter muscle volume, clinical effect of aboBoNT-A treatment was observed from 2 to 4 weeks $[25,28]$, and for jowls, platysmal bands, marionette lines, neck volume and oral commissures, improvement was observed at the 15- and 30-day follow-up visits [24]. 
Table 3. Summary of efficacy and safety outcomes.

\begin{tabular}{|c|c|c|c|c|c|}
\hline \multirow[b]{2}{*}{ Study } & \multicolumn{3}{|c|}{ Efficacy } & \multicolumn{2}{|c|}{ Safety } \\
\hline & Assessment Methods & Clinical Effect & Key Findings & AEs Reported & $\begin{array}{c}\text { Pain and/or Other Safety } \\
\text { Findings }\end{array}$ \\
\hline Awaida et al. 2018 [26] & $\begin{array}{l}\text { Validated photonumeric scales. } \\
\text { Investigator Global Aesthetic } \\
\text { Improvement Scale used to } \\
\text { assess improvement in the } \\
\text { overall appearance of the lower } \\
\text { face and neck }\end{array}$ & NR & $\begin{array}{l}\text { There was statistically significant } \\
\text { improvement in jowls }(p<0.0001) \text {, } \\
\text { platysmal bands with contraction } \\
(p<0.0001) \text { and neck volume } \\
(p<0.0008) 15 \text { days post-treatment } \\
\text { compared with pre-treatment } \\
\text { There was no improvement in } \\
\text { platysmal bands at rest, marionette } \\
\text { lines and oral commissures }\end{array}$ & $\begin{array}{l}\text { Injection-point ecchymosis } \\
\text { lasting } 2 \text { days ( } \mathrm{n}=3 \text { with micro } \\
\text { injections of aboBoNT-A, } \mathrm{n}=6 \\
\text { with Nefertiti technique) } \\
\text { Mild dysphagia lasting } 2 \text { weeks } \\
\text { ( } \mathrm{n}=1 \text { with Nefertiti technique) }\end{array}$ & $\begin{array}{l}\text { Mean (SD) VAS scores for pain } \\
\text { from injections were } 4.6(2.3) \text { for } \\
\text { the micro injection technique and } \\
0.6(2.3) \text { for Nefertiti technique } \\
\text { (on scale of } 0-10 \text { ) }\end{array}$ \\
\hline Chang et al. 2018 [27] & Digital image correlation & $\begin{array}{l}\text { Improvement was observed } \\
\text { at first 14-day follow-up } \\
\text { Duration: } 90 \text { days (final } \\
\text { follow-up) }\end{array}$ & $\begin{array}{l}\text { At day } 14 \text {, there were significant } \\
\text { reductions in the magnitude of strain } \\
\text { in the cheek }(12 \% ; p=0.001) \text {, chin } \\
\text { ( } 7.8 \% ; p=0.022) \text {, marionette lines } \\
(17 \% ; p<0.001) \text {, upper lip }(6.3 \% \text {; } \\
p=0.001) \text { and perioral region as a } \\
\text { whole }(9.3 \% ; p=0.001) \text {. There was a } \\
5.9 \% \text { reduction in nasolabial folds } \\
\text { (not statistically significant, } p=0.057) \\
\text { At day } 14 \text {, there were significant } \\
\text { increases in perioral volume in the } \\
\text { nasolabial folds ( } p=0.004) \text {, } \\
\text { marionette lines }(p=0.006) \text {, upper lip } \\
(p=0.004) \text { and oral commissures } \\
(p<0.001) \\
\text { There were further reductions in } \\
\text { strain at day } 90 \\
\text { There was no significant change in } \\
\text { facial strain symmetry from baseline } \\
\text { to day } 90 \\
\text { By day } 90 \text {, only the increase in } \\
\text { volume in the marionette lines } \\
\text { remained significant }(p=0.039), \text { with } \\
\text { volumes in the other three regions } \\
\text { returning close to baseline levels }\end{array}$ & NR & $\begin{array}{l}\text { No patients had any } \\
\text { complications as a result of } \\
\text { injections }\end{array}$ \\
\hline
\end{tabular}


Table 3. Cont.

\begin{tabular}{|c|c|c|c|c|c|}
\hline \multirow[b]{2}{*}{ Study } & \multicolumn{3}{|c|}{ Efficacy } & \multicolumn{2}{|c|}{ Safety } \\
\hline & Assessment Methods & Clinical Effect & Key Findings & AEs Reported & $\begin{array}{c}\text { Pain and/or Other Safety } \\
\text { Findings }\end{array}$ \\
\hline Hevia 2010 [21] & NR & NR & NR & $\begin{array}{l}\text { No AEs were reported for } \\
\text { patients who received treatment }\end{array}$ & NR \\
\hline Hexsel et al. 2013 [30] & $\begin{array}{l}\text { Dermatological evaluation, } \\
\text { wrinkle severity assessment, } \\
\text { review of standardized } \\
\text { photographs }\end{array}$ & $\begin{array}{l}\text { Improvement was observed } \\
\text { at first 4-week follow-up } \\
\\
\text { Duration: up to } 20 \text { weeks } \\
\text { (participants reporting } \\
\text { improvement in nasal } \\
\text { wrinkles and lower eyelid } \\
\text { wrinkles at follow-up) }\end{array}$ & $\begin{array}{l}\text { There was a reduction in the severity } \\
\text { of marionette lines between baseline } \\
\text { and week } 4 \text { ( } p \text { value not reported) } \\
\text { At week } 4 \text {, most of the participants } \\
\text { presented at least } 50 \% \text { improvement } \\
\text { in lower eyelid wrinkles, nasal } \\
\text { wrinkles, perioral wrinkles and chin } \\
\text { At week } 16 \text {, more than } 15 \% \text { of the } \\
\text { participants maintained at least } 50 \% \\
\text { improvement in lower eyelid } \\
\text { wrinkles, and more than } 50 \% \text { of the } \\
\text { participants maintained at least } 25 \% \\
\text { improvement in nasal and lower } \\
\text { eyelid wrinkles } \\
\text { At week } 20,18 \% \text { of participants } \\
\text { maintained at least } 25 \% \text { improvement } \\
\text { in nasal wrinkles and } 28 \% \text { of the } \\
\text { subjects maintained at least } 25 \% \\
\text { improvement in lower eyelid } \\
\text { wrinkles }\end{array}$ & $\begin{array}{l}\text { Excessive perioral weakness }(\mathrm{n}= \\
30 / 77 \text {, AEs linked to injection } \\
\text { dose) } \\
\text { Lip asymmetry }(\mathrm{n}=3) \\
\text { No serious AEs }\end{array}$ & $\begin{array}{l}\text { Pain after injection was reported } \\
\text { in two participants (although the } \\
\text { area of face treated in these } \\
\text { participants was not reported; } \\
\text { thus, these may be participants } \\
\text { that received treatment in the } \\
\text { upper face) }\end{array}$ \\
\hline Hexsel et al. 2013 [29] & NR & NR & NR & NR & NR \\
\hline Jabbour et al. 2017 [24] & Validated photonumeric scales & $\begin{array}{l}\text { Improvement was observed } \\
\text { at 15- and 30-day follow-up } \\
\text { visits } \\
\text { Duration: NR }\end{array}$ & $\begin{array}{l}\text { There was significant improvement } \\
\text { in wrinkles /lines in the platysmal } \\
\text { bands with contraction }(p<0.001) \\
\text { and rest }(p<0.009) \\
\text { No significant improvement } \\
\text { observed in the jowls, marionette } \\
\text { lines and oral commissures } \\
\text { No significant improvement in neck } \\
\text { volume scores }\end{array}$ & $\begin{array}{l}\text { Injection-point ecchymosis }(\mathrm{n}=5) \\
\text { Mild dysphagia and minor neck } \\
\text { muscle weakness for } 2 \text { weeks } \\
\text { post-injection }(\mathrm{n}=1)\end{array}$ & $\begin{array}{l}\text { Mean (SD) VAS score for pain } \\
\text { from injections was } 1.2 \text { (1.1) (on } \\
\text { scale of } 0-10 \text { ) }\end{array}$ \\
\hline
\end{tabular}


Table 3. Cont.

Efficacy

Safety

Study

Assessment Methods

Clinical Effect

Key Findings

AEs Reported

\section{Pain and/or Other Safety}

Findings

Crunching power is decreased

(n = 192)

\section{Onset: 2-4 weeks}

Kim et al. 2005 [25]

Ultrasonogram

Duration: maximum effect

was at $10-12$ weeks

At 3 months, the mean thickness of

the masseter muscle was reduced

by $31 \%$

In crunching, muscle is

protruded $(n=38)$

Unnatural smiling appearance

$(\mathrm{n}=8)$

Disappearance of facial dimple

$(\mathrm{n}=4)$

A decrease in the degree of gum

display was measured in all patient

20-30 days following treatment

Clinician assessment of

photographs

(with the aid of two computer

programs, the area of gum

exposed was measured

before and after treatment, to

evaluate the level of

improvement)

\section{Onset: NR}

Duration: 3-5 months
The average improvement of gingival

exposure was:

$75.09 \%$ in the overall sample

$96 \%$ in those with anterior gummy

$96 \%$

Asymmetric smile $(\mathrm{n}=1)$

mile

Asymmetric smile ( $\mathrm{n}=1)$

$61.06 \%$ in those with posterio

gummy smile

$90.1 \%$ in those with mixed gummy

Difficulty in smiling $(\mathrm{n}=1)$

smile

$71.93 \%$ in those with asymmetric

gummy smile 
Table 3. Cont.

Efficacy

Safety

Study

Assessment Methods

Clinical Effect

Onset: In some cases

instantaneous, but in most

Petchngao-vilai 2009 [23]

Assessment of photographs ases changes seen within

5-10 days

Duration: 10-14 week
Pain and/or Other Safety

Findings

$24.9 \%$ of participants $(n=65)$ attained

high improvements with cheek lift,

softening of nasolabial folds and

re-defining of the facial contour ${ }^{1}$

$65.52 \%$ of participants $(n=171)$

attained moderate improvements

with cheek lift and facial contouring

Minor facial asymmetry $(\mathrm{n}=8)$

NR

$9.58 \%$ of participants $(n=25)$ attained

minimal improvements of facial

contour $^{1}$

At 3 months, the volume of the masseter muscle was: decreased to

$69.36 \%$ of baseline volume on the

right side; decreased to $70.44 \%$ of

baseline volume on the left side; and

reduced by $30 \%$ overall $(p<0.001)$

There was no significant reduction in
the volume of the other masticating

muscles (temporalis, medial

pterygoid, lateral pterygoid)
compared with baseline $(p>0.001)$

CT scan to measure muscle

Onset: 2 weeks

Yu et al. 2007 [28]

on a VAS to record facial scores

Duration: NR

Mean score reported by patients on

facial improvement reached its maximum of 7.1 at 6 months

One patient reported no change to facial appearance at any point during the study

At the end of the study, only one

patient reported a meaningful score
Injection-point ecchymosis and swelling the day after injection

that subsided 1 week later $(\mathrm{n}=1)$

Soreness of bilateral masseters 1

day after the injection, which was agravated when chewing food $(\mathrm{n}=4)$

Easily fatigued while chewing food 2 days after the injection $(\mathrm{n}=10)$

Bite weakness while eating vegetables or thick meat $(\mathrm{n}=8)$

Less food intake because of more chewing effort required, but there was no interference to daily life $(\mathrm{n}=1)$

Depression of the cheek on the right side $(\mathrm{n}=2)$ 
A duration of action for aboBoNT-A treatment of 3-5 months was reported for gummy smile [22], 10-14 weeks for mid-face lifting involving injection of the platysma and lateral part of the orbicularis oculi [23] and improvement was observed up to 20 weeks following aboBoNT-A treatment of wrinkles in the middle and lower face [30] and up to 90 days following aboBoNT-A treatment of marionette lines [27]. One study of aboBoNT-A treatment for reduction of masseter muscle volume also reported maximum effect at 10-12 weeks following treatment [25].

All eight studies reported improvements following aboBoNT-A treatment in the neck, and middle or lower face [22-28,30]. Two studies that analysed patients from the same study sample ( $n=30$ [100\% women]) demonstrated significant improvements in scores on a photonumeric scale [31,32] when measuring wrinkles/lines in the platysmal bands at 15 days following treatment compared with before treatment [24,26]. Two studies, a non-randomized controlled trial ( $\mathrm{n}=32$ [100\% women]) [27] and an RCT ( $\mathrm{n}=85$ [82 women; 3 men]) [30], showed reductions in the magnitude of strain in the marionette lines, perioral area and chin, at follow-up times of 2-4 weeks. Improvements were also demonstrated, in single studies, for jowls [26], lip [27], and eyelid and nasal wrinkles [30]. Two studies investigated the change in masseter muscle volume at 3 month after injection with aboBoNT-A [25,28]. Kim et al. ( $\mathrm{n}=383$ [355 women; 28 men]) [25] and Yu et al. ( $\mathrm{n}=10$ [100\% women]) [28] both demonstrated reductions in masseter muscle volume by approximately $30 \%$; these studies used an ultrasonogram and computed tomography (CT) scan, respectively, to measure muscle volume. Finally, one study investigated the degree of gum display in 16 participants with gummy smile [22]. Findings showed that there were improvements in anterior, posterior, mixed and asymmetric gummy smile of $61-96 \%$, at follow-up 20-30 days following treatment.

\subsection{Safety Outcomes}

Nine studies reported on the safety outcomes associated with the injection of aboBoNT$A$ in the neck, and upper, middle and lower areas of the face (Table 3) [21-28,30]. The adverse events (AEs) or temporary side effects associated with aboBoNT-A treatment were mild or moderate and occurred infrequently, as follows: injection-point ecchymosis [24,26,33]; lip/face asymmetry [22,23,28,30]; difference in crunching power [25,28]; mild dysphagia following injections in the neck [24,26]; excessive perioral weakness [30]; minor neck muscle weakness [24]; unnatural smiling appearance [25] and disappearance of facial dimple [25]. One of the studies observed AEs under a novel technique, micro injections [26], and the Nefertiti technique [34]. More events of ecchymosis were observed with the Nefertiti technique than with the micro injections ( $n=6$ vs. $n=3$ ) and mild dysphagia was observed with the Nefertiti technique but not with micro injections [26]. Two studies reported that there were no AEs associated with aboBoNT-A treatment $[21,27]$. Three studies assessed pain after injection using patient-rated scales [24,26,28]. Mean visual analog scale (VAS) scores for pain from injections ranged from 0.6 to 4.6 on scale of 0 to 10 [24,26], and a mean score of 3 was reported in one study using VAS scores of 1 to 5 [28].

\subsection{Patient Satisfaction and Quality of Life}

Six studies reported patients satisfaction outcomes [22,24-27,29] and one study assessed health-related quality of life (Supplementary Materials Table S1: Summary of patient satisfaction and quality of life outcomes) [29]. Most studies used simple surveys, asking the patient whether they were satisfied with their results. Only one study [27] used a formal assessment that has been evaluated elsewhere: the FACE-Q survey $[33,35,36]$. Five studies showed that $84-100 \%$ of participants were satisfied with the results of their treatment (Figure 3) [22,24-26,29]. In one study, the participants were 22.2\% ( $p=0.014)$ more satisfied with their overall facial appearance at day 14 compared with baseline [27]. In one study that used two techniques, $72 \%$ of patients preferred micro injections, $20 \%$ preferred the Nefertiti technique and $8 \%$ had no preference [26]. In the study that assessed quality of life, which used the World Health Organization Quality of Life-Brief Version questionnaire 
(WHOQOL-BREF), there was a significant improvement in the physical quality of life domain between baseline and 4 weeks. When comparing total dose groups, a medium dose group (166-205 U) had significantly better physical, psychological and social relationships quality of life scores than the low (120-165 U) and high (206-250 U) dose groups [29].

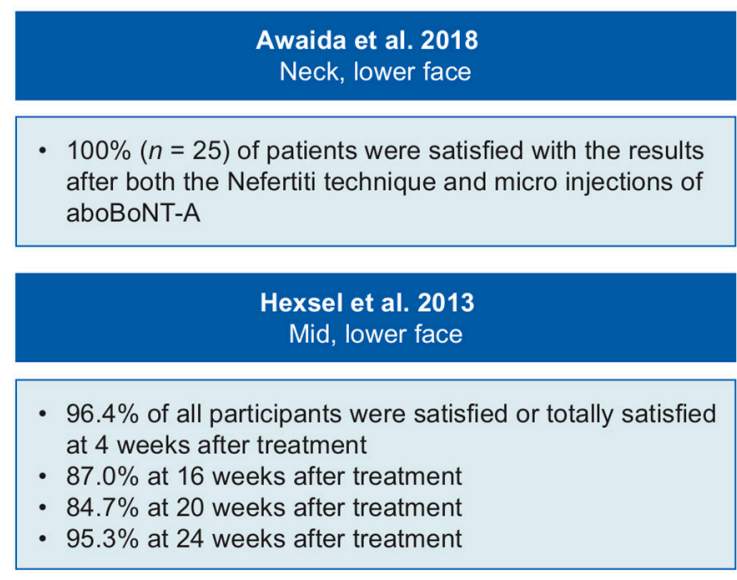

Figure 3. Patient satisfaction with abobotulinumtoxinA (aboBoNT-A) treatment. References: Awaida et al. [26]; Hexsel et al. [29]; Mazzuco and Hexsel [22]; Kim et al. [25]; Jabbour et al. [24].

\section{Discussion}

To our knowledge, this is the first published SLR describing the evidence on the treatment approaches, efficacy and safety outcomes associated with the use of aboBoNT-A specifically for cosmetic treatment of the neck, and middle and lower areas of the face.

This SLR identified several studies reporting a range of treatment approaches and provides insight into the dose, number of injection points, injection frequency and toxin dilution for aboBoNT-A treatment of the lower and middle areas of the face and the neck. A broad range of treatment approaches were reported, although there were some commonalities amongst some studies, for example in the aboBoNT-A dilution used ( 2 or $2.5 \mathrm{~mL}$ of normal saline to dilute $500 \mathrm{U}$ of aboBoNT-A).

A broad range of efficacy outcomes were measured in the different studies; measures to examine improvement following treatment included validated photonumeric scales, digital image correlation and clinician assessment of photographs. To enable the comparison of data across studies, further research using comparable outcome measures would be beneficial.

All studies identified in this SLR reported that aboBoNT-A treatment is effective for cosmetic use, regardless of the indication. Studies that asked if patients were satisfied with the results of aboBoNT-A treatment showed a high proportion of positive responses. It is not clear from the evidence if satisfaction is driven by the results themselves, onset or duration of results, or all of the above. In this review, five of ten studies reported duration of action for aboBoNT-A treatment and found that duration of action was 2-5 months across various indications $[22,23,25,27,30]$. This is similar to findings from an international expert consensus on both facial rejuvenation and primary hyperhidrosis, which stated that duration of aboBoNT-A effect was up to 4-6 months for repeated treatment, and could be more than 6 months in some cases [16]. In addition, a systematic review of aboBoNT-A treatment of the upper face found that a typical duration of action was 4 months, across 18 studies [37]. Data on pain experienced during injection were limited, with only three studies reporting this outcome. In addition, only one study examined quality of life outcomes [29]. 
No serious AEs associated with aboBoNT-A use were reported in any of the studies. One potential serious AE associated with cosmetic injection of botulinum toxins is dysphagia, which can occur as a result of paralysis of muscles near the injection area [38]. Only one case of dysphagia was reported among the ten studies in the current review and its severity was mild. Possibly this is owing to the dose levels among these studies, as risk of dysphagia may depend on dose [39].

A strength of this SLR is that no country and date limits were included in the protocol; therefore, the results provide evidence on the global use and treatment patterns of aboBoNTA for the neck and lower and middle areas of the face.

However, overall, the number of studies identified in the SLR was low, with many studies identified in the electronic searches looking only at upper regions of the face and therefore being excluded during citation screening. The studies were limited to those published in English and further studies in other languages were not included, which may contribute to the amount of published evidence identified in this SLR being low. Furthermore, the low number of studies identified and the broad range of approaches reported, prevent any statistical analysis of the data combined from different studies.

The aim of this systematic review was not to generate data that would be used to seek regulatory approval for the use of aboBoNT-A as a cosmetic treatment of the neck, and middle and lower areas of the face and none of the studies included in the SLR are funded by manufacturers of aboBoNT-A. The SLR was conducted by the investigators with better scientific understanding as the main aim.

\section{Conclusions}

The findings of this SLR demonstrate that aboBoNT-A is used for a range of cosmetic treatments in the lower and middle areas of the face, and in the neck, with positive outcomes for patients and a low complication rate. However, the number of studies identified was low and a broad range of approaches was identified. Further research is needed to establish uniform protocols to allow consistent treatment approaches and optimize treatment outcomes for patients.

\section{Materials and Methods}

\subsection{Search Strategy}

The SLR was performed to identify studies relevant to at least one of the following four key areas: (i) treatment approaches, (ii) efficacy outcomes, (iii) safety outcomes and (iv) patient-reported outcomes, including patient satisfaction and quality of life. The literature searches were conducted in August 2019 in the following electronic databases: (1) MEDLINE In-Process \& Other Non-Indexed Citations and OVID MEDLINE, 1946-present, (2) Embase, 1974-present and (3) Cochrane Library, comprising American College of Physicians Journal Club, Cochrane Database of Systematic Reviews, Cochrane Central Register of Clinical Trials, Evidence-Based Medicine Reviews Database of Abstracts of Reviews of Effects, National Health Service Economic Evaluation Database, Health Technology Assessment Database and all entries in Evidence-Based Medicine Reviews (Table S2: Searches carried out in: Ovid MEDLINE, all segments, 1946 to present; Embase 1974 to 18 July 2019; and Cochrane (CDSR, DARE, CENTRAL, NHS EED, The HTA database, and ACP Journal Club) 23 August 2019). The SLR is fully compliant with the 2009 Preferred Reporting Items for Systematic reviews and Meta-Analyses (PRISMA) guidelines [40]. There is no protocol available for this SLR. The bibliographies of pertinent narrative reviews identified in the SLR and proceedings from The American Academy of Dermatology and European Society for Dermatologic Research annual congresses (2017-2019) were searched for relevant studies.

\subsection{Eligibility Criteria}

The title and abstract of identified publications were screened manually against pre-defined eligibility criteria for each objective (Table S3: Eligibility criteria used in the 
systematic literature review). The searches were limited to human studies published in English. OSs, non-randomized controlled trials and RCTs were included. Narrative reviews were included for the first screening so that the bibliographies could be searched for any relevant OSs, non-randomized controlled trials or RCTs cited; narrative reviews were excluded at full-text review. Full-text versions of all publications meeting the eligibility criteria at first screening were reviewed. Data from eligible studies were extracted manually into pre-defined summary tables.

\subsection{Data Extraction}

Information extracted from relevant studies included study design, context (aims / objectives, outcomes/endpoint, disease type, sample size, comparator group, followup period), participants (demographics, disease duration), treatment approaches (area, dose and dilution, number of injection points and injection frequency), efficacy outcomes (wrinkle/line assessment, gum display, global aesthetic improvement scale, onset/duration of action), safety outcomes (AEs), patient satisfaction and quality of life.

Supplementary Materials: The following are available online at https:/ /www.mdpi.com/2072-6 651/13/2/169/s1, Table S1: Summary of patient satisfaction and quality of life outcomes, Table S2: Searches carried out in: Ovid MEDLINE, all segments, 1946 to present; Embase 1974 to 18 July 2019; and Cochrane (CDSR, DARE, CENTRAL, NHS EED, The HTA database, and ACP Journal Club) 23 August 2019, Table S3: Eligibility criteria used in the systematic literature review.

Author Contributions: H.G., I.G., R.S., I.P. and A.R. contributed to the conceptualization of this review and the writing of the manuscript. All authors have read and agreed to the published version of the manuscript.

Funding: This study was sponsored by Ipsen.

Institutional Review Board Statement: Not applicable.

Informed Consent Statement: Patient consent was not necessary because content is based on data that are already published.

Data Availability Statement: No new data were created or analyzed in this study. Data sharing is not applicable to this article.

Acknowledgments: The authors thank Alison Baird of Oxford PharmaGenesis Ltd., Oxford, UK for providing medical writing support, which was sponsored by Ipsen in accordance with Good Publication Practice guidelines.

Conflicts of Interest: Hassan Galadari and Ibrahim Galadari have no conflicts of interest to disclose; Inna Prygova is an Ipsen employee; Alessio Redaelli reports personal fees from Ipsen during the conduct of the study and personal fees from Ipsen and Fillmed Laboratories and other financial activities from OEO Florence Editor outside of the submitted work; Riekie Smit reports honoraria for conference presentations or workshops received from Ipsen, Fillmed Laboratories, Hansbiomed and Inova Pharmaceuticals. The sponsor, Ipsen, was not involved in the study design, data collection, data analysis, manuscript preparation or publication decisions.

\section{References}

1. American Society for Dermatologic Surgery. 2019 ASDS Consumer Survey on Cosmetic Dermatologic Procedures. Available online: https:/ / www.asds.net/medical-professionals/practice-resources / asds-consumer-survey-on-cosmetic-dermatologicprocedures (accessed on 16 February 2021).

2. American Society of Plastic Surgeons. 2016 National Plastic Surgery Statistics. Available online: https://d2wirczt3b6wjm. cloudfront.net/News/Statistics/2016/2016-plastic-surgery-statistics-report.pdf (accessed on 16 February 2021).

3. International Society of Aesthetic Plastic Surgery. ISAPS International Survey on Aesthetic/Cosmetic Procedures Performed in 2019. Available online: https://www.isaps.org/wp-content/uploads/2020/12/Global-Survey-2019.pdf (accessed on 16 February 2021).

4. Sundaram, H.; Signorini, M.; Liew, S.; de Almeida, A.R.T.; Wu, Y.; Vieira Braz, A.; Fagien, S.; Goodman, G.J.; Monheit, G.; Raspaldo, H.; et al. Global aesthetics consensus: Botulinum toxin type A-Evidence-based review, emerging concepts, and consensus recommendations for aesthetic use, including updates on complications. Plast. Reconstr. Surg. 2016, 137, 518e-529e. [CrossRef]

5. Huang, W.; Foster, J.A.; Rogachefsky, A.S. Pharmacology of botulinum toxin. J. Am. Acad. Dermatol. 2000, 43, 249-259. [CrossRef] 
6. Pirazzini, M.; Rossetto, O.; Eleopra, R.; Montecucco, C. Botulinum neurotoxins: Biology, pharmacology, and toxicology. Pharmacol. Rev. 2017, 69, 200-235. [CrossRef] [PubMed]

7. Albanese, A. Terminology for preparations of botulinum neurotoxins: What a difference a name makes. JAMA 2011, 305, 89-90. [CrossRef]

8. Samizadeh, S.; De Boulle, K. Botulinum neurotoxin formulations: Overcoming the confusion. Clin. Cosmet. Investig. Dermatol. 2018, 11, 273-287. [CrossRef]

9. Field, M.; Splevins, A.; Picaut, P.; van der Schans, M.; Langenberg, J.; Noort, D.; Snyder, D.; Foster, K. AbobotulinumtoxinA $\left(\right.$ Dysport $\left.^{\circledR}\right)$, onabotulinumtoxinA (Botox ${ }^{\circledR}$ ), and incobotulinumtoxinA (Xeomin ${ }^{\circledR}$ ) neurotoxin content and potential implications for duration of response in patients. Toxins 2018, 10, E535. [CrossRef] [PubMed]

10. United States Food and Drug Administration. DYSPORT®(abobotulinumtoxinA) for Injection, for Intramuscular UsePrescribing Information. Available online: https:/ / www.accessdata.fda.gov/drugsatfda_docs/label/2016/125274s107lbl.pdf (accessed on 16 February 2021).

11. United States Food and Drug Administration. XEOMIN (incobotulinumtoxinA) for Injection, for Intramuscular or Intraglandular Use-Prescribing Information. Available online: https://www.accessdata.fda.gov/drugsatfda_docs/label/2020/125360s086s092 lbl.pdf (accessed on 16 February 2021).

12. Walker, T.J.; Dayan, S.H. Comparison and overview of currently available neurotoxins. J. Clin. Aesthetic. Dermatol. 2014, 7, 31-39.

13. Electronic Medicines Compendium. Azzalure, 125 Speywood Units, Powder for Solution for Injection-Summary of Product Characteristics. Available online: https:/ / www.medicines.org.uk/emc/product/6584/smpc (accessed on 16 February 2021).

14. Ascher, B.; Talarico, S.; Cassuto, D.; Escobar, S.; Hexsel, D.; Jaen, P.; Monheit, G.D.; Rzany, B.; Viel, M. International consensus recommendations on the aesthetic usage of botulinum toxin type A (Speywood Unit)—Part II: Wrinkles on the middle and lower face, neck and chest. J. Eur. Acad. Dermatol. Venereol. 2010, 24, 1285-1295. [CrossRef] [PubMed]

15. Maas, C.; Kane, M.A.; Bucay, V.W.; Allen, S.; Applebaum, D.J.; Baumann, L.; Cox, S.E.; Few, J.W.; Joseph, J.H.; Lorenc, Z.P.; et al. Current aesthetic use of abobotulinumtoxinA in clinical practice: An evidence-based consensus review. Aesthetic Surg. J. 2012, 32, 8S-29S. [CrossRef] [PubMed]

16. Redaelli, A.; Saromytskaya, A.; Rowland Payne, C.; Manturova, N.; Battistella, M.; Saban, Y.; Panova, O.; Wollina, U.; Landau, M.; Atamanov, V.; et al. International expert consensus on the use of AboBotulinum Toxin A (AboTA) for facial rejuvenation and primary hyperhidrosis. Cosmet. Med. 2017, 2.17, 70-80.

17. Rzany, B.; Fratila, A.A.; Fischer, T.C.; Hilton, S.; Pavicic, T.; Rothhaar, A.; Sattler, G.; Sommer, B.; Pickett, A. Recommendations for the best possible use of botulinum neurotoxin type a (Speywood units) for aesthetic applications. J. Drugs Dermatol. JDD 2013, $12,80-84$.

18. Bonaparte, J.P.; Ellis, D.; Quinn, J.G.; Ansari, M.T.; Rabski, J.; Kilty, S.J. A comparative assessment of three formulations of botulinum toxin A for facial rhytides: A systematic review and meta-analyses. Syst. Rev. 2013, 2, 40. [CrossRef] [PubMed]

19. Nahai, F.; Lorenc, Z.P.; Kenkel, J.M.; Fagien, S.; Hirmand, H.; Nestor, M.S.; Sclafani, A.P.; Sykes, J.M.; Waldorf, H.A. A review of abobotulinumtoxinA (Dysport). Aesthetic 2013, 33, 13S-17S. [CrossRef]

20. Redaelli, A.; Battistella, M. Abobotulinum toxin A and fillers for facial rejuvenation: My experience and technique. Glob. Dermatol. 2017, 4, 1-4.

21. Hevia, O. Retrospective review of 500 patients treated with abobotulinumtoxinA. J. Drugs Dermatol. JDD 2010, 9, 1081-1084.

22. Mazzuco, R.; Hexsel, D. Gummy smile and botulinum toxin: A new approach based on the gingival exposure area. J. Am. Acad. Dermatol. 2010, 63, 1042-1051. [CrossRef] [PubMed]

23. Petchngaovilai, C. Midface lifting with botulinum toxin: Intradermal technique. J. Cosmet. Dermatol. 2009, 8, 312-316. [CrossRef] [PubMed]

24. Jabbour, S.F.; Kechichian, E.G.; Awaida, C.J.; Tomb, R.R.; Nasr, M.W. Botulinum toxin for neck rejuvenation: Assessing efficacy and redefining patient selection. Plast. Reconstr. Surg. 2017, 140, 9e-17e. [CrossRef]

25. Kim, N.H.; Chung, J.H.; Park, R.-H.; Park, J.B. The use of botulinum toxin type A in aesthetic mandibular contouring. Plast. Reconstr. Surg. 2005, 115, 919-930. [CrossRef]

26. Awaida, C.J.; Jabbour, S.F.; Rayess, Y.A.; El Khoury, J.S.; Kechichian, E.G.; Nasr, M.W. Evaluation of the microbotox technique: An algorithmic approach for lower face and neck rejuvenation and a crossover clinical trial. Plast. Reconstr. Surg. 2018, 142, 640-649. [CrossRef] [PubMed]

27. Chang, C.S.; Chang, B.L.; Lanni, M.; Wilson, A.J.; Beer, J.; Percec, I. Perioral rejuvenation: A prospective, quantitative dynamic three-dimensional analysis of a dual modality treatment. Aesthetic 2018, 38, 1225-1236. [CrossRef]

28. Yu, C.C.; Chen, P.K.T.; Chen, Y.R. Botulinum toxin A for lower facial contouring: A prospective study. Aesthetic Plast. Surg. 2007, 31, 445-451. [CrossRef]

29. Hexsel, D.; Brum, C.; Porto, M.D.; Soirefmann, M.; Siega, C.; Schilling-Souza, J.; Rodrigues, T.C. Quality of life and satisfaction of patients after full-face injections of abobotulinum toxin type A: A randomized, phase IV clinical trial. J. Drugs Dermatol. JDD 2013, 12, 1363-1367. [PubMed]

30. Hexsel, D.; Brum, C.; Porto, M.D.; Soirefmann, M.; Siega, C.; Schilling-Souza, J.; Rodrigues, T.C. Full-face injections of variable total doses of abobotulinum toxin type A: Arandomized, phase IV clinical trial of safety and efficacy. J. Drugs Dermatol. JDD 2013, 12, 1356-1362. [PubMed] 
31. Geister, T.L.; Blessmann-Gurk, B.; Rzany, B.; Harrington, L.; Gortelmeyer, R.; Pooth, R. Validated assessment scale for platysmal bands. Dermatol. Surg. 2013, 39, 1217-1225. [CrossRef] [PubMed]

32. Gupta, S.; Biskup, N.; Mattison, G.; Leis, A. Development and validation of a clinical assessment tool for platysmal banding in cervicomental aesthetics of the female neck. Aesthetic Surg. J. 2015, 35, NP141-NP146. [CrossRef]

33. Chang, B.L.; Wilson, A.J.; Taglienti, A.J.; Chang, C.S.; Folsom, N.; Percec, I. Patient perceived benefit in facial aesthetic procedures: FACE-Q as a tool to study botulinum toxin injection outcomes. Aesthetic Surg. J. 2016, 36, 810-820. [CrossRef]

34. Levy, P.M. The 'Nefertiti lift': A new technique for specific re-contouring of the jawline. J. Cosmet. Laser Ther. 2007, 9, 249-252. [CrossRef] [PubMed]

35. Klassen, A.F.; Cano, S.J.; Scott, A.; Snell, L.; Pusic, A.L. Measuring patient-reported outcomes in facial aesthetic patients: Development of the FACE-Q. Facial Plast. Surg. 2010, 26, 303-309. [CrossRef] [PubMed]

36. Pusic, A.L.; Klassen, A.F.; Scott, A.M.; Cano, S.J. Development and psychometric evaluation of the FACE-Q satisfaction with appearance scale: A new patient-reported outcome instrument for facial aesthetics patients. Clin. Plast. Surg. 2013, 40, 249-260. [CrossRef]

37. Nestor, M.; Cohen, J.L.; Landau, M.; Hilton, S.; Nikolis, A.; Haq, S.; Viel, M.; Andriopoulos, B.; Prygova, I.; Foster, K.; et al. Onset and duration of abobotulinumtoxinA for aesthetic use in the upper face: A systematic literature review. J. Clin. Aesthetic Dermatol. 2020, 13, E56-E83.

38. Yiannakopoulou, E. Serious and long-term adverse events associated with the therapeutic and cosmetic use of botulinum toxin. Pharmacology 2015, 95, 65-69. [CrossRef] [PubMed]

39. Eleopra, R.; Tugnoli, V.; Caniatti, L.; De Grandis, D. Botulinum toxin treatment in the facial muscles of humans: Evidence of an action in untreated near muscles by peripheral local diffusion. Neurology 1996, 46, 1158-1160. [CrossRef] [PubMed]

40. PRISMA. Transparent Reporting of Systematic Reviews and Meta-Analyses. Available online: http://www.prisma-statement.org/ (accessed on 16 February 2021). 